\title{
Helle Gotved 1912-2006
}

\section{Af Bo Vestergård Madsen}

Hvor skal man begynde, hvor skal man slutte? For Helle Gotved sluttede det den 19.6.2006, da hun ikke længere bevægede sig, men i bogstaveligste forstand sov stille ind. I hendes gemmer, som jeg fik til opgave at gennemgå, fandt jeg et brev fra skuespilleren Anne-Marie Helger. Altid en sær oplevelse at læse breve, som med ét ændrer status fra personlig korrespondance til kildemateriale. Jeg tillader mig at citere fra det: »Tank, hvad du betyder for så mange det er nu et stort livsvcerk «. Sætningen sammentrækker på bedste vis det, som jeg som idrætshistoriker kan registrere og som privatperson har oplevet: Folk, der helt spontant, når talen faldt på Helle Gotved, udbryder: »Hun fik da udrettet noget«. Det er ikke det værste eftermæle at få. Det smukkeste, det, vi andre pædagoger-på-en-elleranden-måde lever på, er vel at sætte noget $\mathrm{i}$ gang hos dem, vi har med at gøre. Det være sig intellektuelt eller kropsligt - og når alt går op i en højere enhed - begge dele. Tanken om, at man gennem sit virke har sat gang i bevægelser - tankestrømme, refleksioner, tiltag, undren - og en bevidsthed om vores liv som den underlige og sammensatte størrelse, det er som en egen privatkrop, der så aldrig bare er vores egen krop. Altid udleveret i bestemte livsvilkår, i samspillet med og mellem andre mennesker, i betydningstilskrivninger, men også underlagt en vilje. Vilje? Hmmm. Nej, aldrig fri, men altid med muligheder. Et spille- og råderum.
Kroppen er der ikke bare, det er ikke blot noget, vi har. Den er også det, vi $g \phi r$ den til. Det er denne indsigt, som Helle Gotved så markant har bidraget med i bedste oplysningstradition: med liv og lyst.

Helle Gotved havde et meget rousseausk udgangspunkt: barnets bevægelser og dets måde at udvikle og tilegne sig kropslige kunnen er ikke blot stadier, der senere resulterer i perfektion og en opløften til kulmination i voksendommen. Nej, barnet bevægelser og ikke mindst dets måde at tilegne sig kunnen på er menneskets læringsmæssige model, det erfaringsmæssige udgangspunkt, som livets læst er skåret over. Barnet springer over, hvor gærdet er lavest. Helle Gotved skriver selv i Mit livs gymnastikhistorie (1994: 154): »Barnet gør kun fremskridt (bogstaveligt talt), når det foregår på den nemmest mulige måde. Det er dér, hvor der er mindst mulig modstand. Slutresultatet er fuldendt. Uanstrengt, enkelt, smukt. Men så begynder forfaldet på grund af livets påvirkninger, såvel af fysisk som af psykisk art«. Gennem et delvist opgør og en delvis videreudvikling af de gymnastiksystemer, som havde været fremherskende (Ling, Bukh, Björkstén og Bertram) gik hun tilbage, startede forfra både som gymnastikpædagog og i synet på det væsentlige. Gymnastikken skulle være der, hvor man gik tilbage til roden, til stammen. Man skulle lære at kunne regulere kroppens tonus, dvs. spænding, ved at vende tilbage 
til de basale kropslige modi: ligge, sidde, gå og stå: »Hvor er фvelsesstoffet? Se i kravlegården «»... min tese er: begynd forfra-ved et nulpunkt. Men fä bevidstheden og forstaelsen med. Gymnastik skal vare et forstandsfag. Den anspandte elev skal lare at give slip og overgive sig til tyngden. Det er basis for bevagelseslceren « (Gotved 1995: 158f.). Gymnastikken skulle være et sted, hvor man vendte tilbage til barndommens verden, men i et voksent univers: bevidstheden skulle med. Og dermed hv-ordene: Hvorfor, hvordan og hvorledes? Se på et barn, der sidder på gulvet, ryggen er ret og overgangen til en ny stilling eller bevægelse foregår flydende og harmonisk. Hvorfor skal vi trækkes med dårlige rygge, hvordan kan det være, at vi accepterer det og hvorledes får vi gjort noget ved det?

At vende tilbage til bevægelsens byggeklodser for at kunne stable os selv på benene igen var kun en del af projektet. I den forstand var det ikke et statisk projekt, tværtimod. Helle Gotved blev stærkt optaget af tyskeren Hinrich Medaus totalgymnastik, som hun oplevede ved en opvisning i Idrætshuset i København 1936. Hun beskrev det selv som »den store oplevelse«, der blev skelsættende. Det, der tryllebandt Helle Gotved, var musikken, der strømmede ud fra Medaus klaver og de totalbevægelser, som pigerne udførte. Ikke med eller til musikken, men gennem musikken: »Medau skabte et dynamisk lydbillede af, hvad man folte i bevagelsen. Ikke en reproduktion af, hvad man så. Det var selve impulsen og forlфbet, der på fremragende vis blev levendegjort $i$ musikken - melodisk spanding og afspanding. Bevagelsen var tidløs og total, levende og gennemstrømmende (Gotved 1995: 33). Det princip, som Medau her var eksponent for, var, at det handlede om at fremme de organiske bevægelser frem for at isolerede. »Alle led var i en uafbrudt sammenhangende beveegelse«, som Helle Gotved selv beskriver oplevelsen (Gotved 1995: 33). Impulsen startede i hofteleddet, hvorefter den spredte sig videre. Og for at fordre bevægelserne og forlænge deres æstetiske udtryk blev køller, bolde og tøndebånd inddraget. Denne åbenbaring blev retningsanvisende for Helle Gotveds arbejde i årene derefter. Og for de dele af det danske gymnastikmiljø, der turde give hoften en så central placering.

Men projektet gik videre endnu. Åndedrættet skulle med. Helle Gotved slog til lyd for, at der var to centrale funktioner ved åndedrættet: »luftskiftet - livets beståen, lydgivningen - kommunikationen « (Gotved 1979: 8). Hun inddrog begge dele i sin gymnastik og gik dermed en radikalt anderledes vej, end den lingianerne og deres arvtagere havde fulgt. Også i den lingske gymnastik var åndedrættet og stemmen med. Sidstnævnte især gennem gymnasternes sang og lederens kommando. Og siden båndoptageren kom ind i gymnastiksalen, var det så som så med sangen. Helle Gotved fik den ide, at lyden igen skulle gives tilbage til gymnasterne. Den skulle ikke kun være noget, der ramte dem i form af tilråb og musik. Det skulle ikke kun dreje sig om at bringe de forfinede lyde - den organiserede sang - tilbage til eleverne. Der skulle igen graves dybere: »En talestemme, der ikke lyder af noget, men kun består af ord, er fattig. For med ord kan vi nok meddele vore tanker - men det er med lyde, vi giver udtryk for vore følelser. Det er åndedrattet igen! De dybeste folelser findes der slet ikke ord for (klageråb, frydeskrig, suk, støn, gråd og latter)《 (Gotved 1979: 7). Kroppen skulle gøres hørlig gennem ledsagende lyde lige fra velværesuk til råb og ledsage bevægelserne til totalitet. At bruge stemmen via åndedrættet skulle bidrage til at reformulere kroppen. Den 


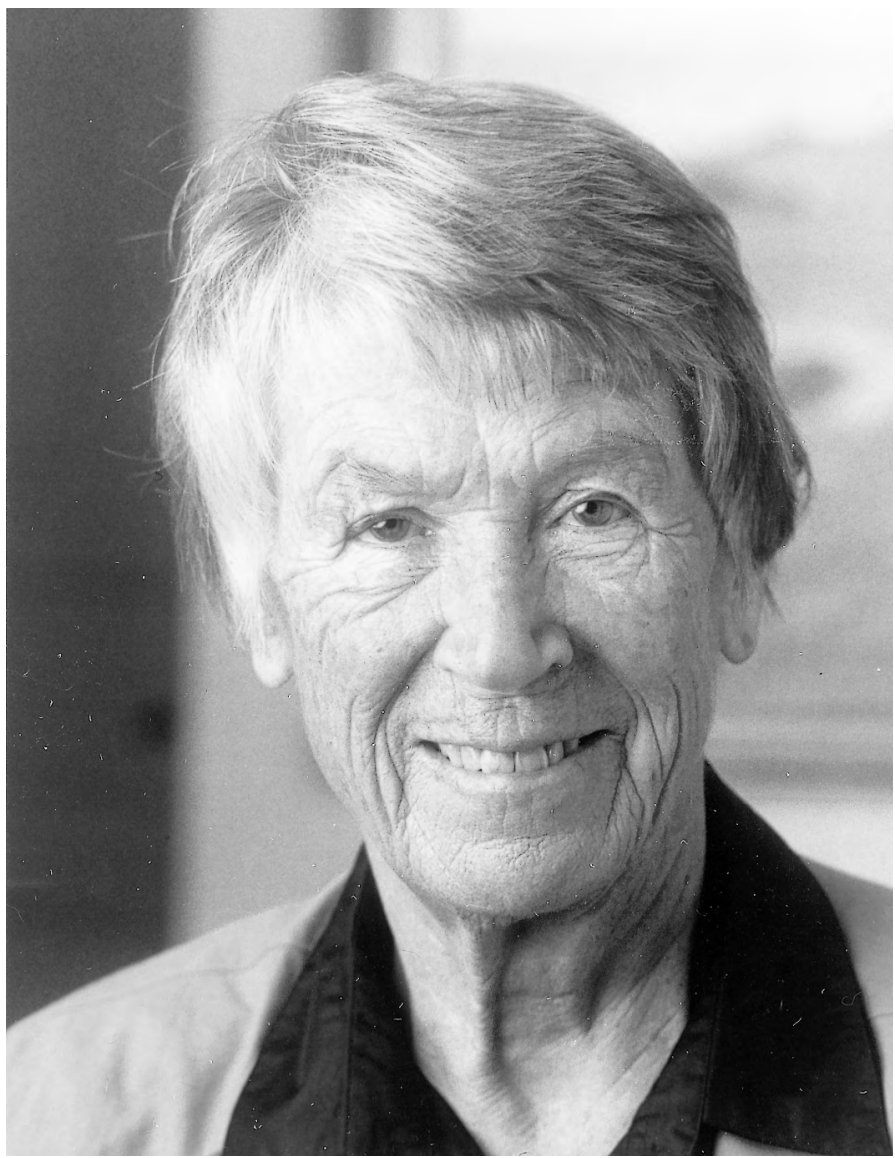

skulle ikke kun være et lydigt redskab i en højere sags tjeneste, men en integreret del af vores personlige udsagn.

Helle Gotveds fortjeneste var ikke mindst, at hun gik skridtet videre i forhold til andre bevægelsespædagoger og ikke mindst læger. Hun lod sig ikke nøje med de moralske pegefingre, men gik dybere ind i kroppen og skrev om tabubelagte emner som inkontinens og seksualitet. Igen var mantraet: hvorfor skal mennesker lade sig hindre, når man gennem arbejde med kroppen kan udvide mulighederne og ens livshorisont? Arbejdet med disse - skal vi sige dybe kropslige elementer - gjorde, at hun kom ud over de snævert idrætslige og gymnastiske miljøer. Det skyldtes ikke mindst hendes kald og evne til at formidle. Hende stemme lød i radioen fra 1966-1992 under titlen »Ha' det bedre «, hvor hun tog skiftende emner op og formidlede budskabet om kroppen som værende alles ejendom - og den enkeltes ansvar. Den stemme, der her lød, er der mange, mange mennesker, der kan huske og genkalde sig. Helle Gotved formåede altså at komme ud til de mange gennem radio, tv, bogudgivelser og foredrag - og ikke mindst til kvinderne, der fik at vide, at en bækkenbund ikke blot var noget, de havde, det var også noget, de kunne gøre noget ved. Der er ganske givet mange kvinder over det gan- 
ske land, som har stået i et tavst, men sublimt arbejdende fællesskab, mens de udførte knibeøvelser i køen på vej til kassen i det lokale supermarked. Selv kaldte Helle Gotved det meget betegnende for sin virksomhed for oplysning, noget hun følte som en forpligtelse.

Denne forpligtelse over for projektet, kombineret med en ustyrlig videbegærlighed og kreativ arbejdsomhed, der blev omsat i konkret og nyskabende gymnastik har gjort, at Helle Gotved indskriver sig på en plads i den danske idrætshistorie. Og går man forbi Vodroffsvej 51 på Frederiksberg, kan man stadig nyde synet af Gymnastikhuset, som Helle Gotveds far, N.H. Rasmussen, fik bygget i 1898 - og måske endnu vigtigere: man kan svagt ane lyden af musik og mennesker, der bevæger sig. Gotvedskolen leverer stadig bevægelsespædagoger, som er udlært efter de grundlæggende principper, som Helle Gotved udarbejdede gennem en menneskealder. Og mange mennesker går stadig til gymnastik i det smukke, gamle hus.

Det er altid svært at vurdere, hvilken og hvor stor betydning, mennesker har haft for deres tid. Meget af det, som Helle Gotved kæmpede for, er i dag selvfølgeligheder - og det er faktisk en god målestok for en succes. At det er vores krop, og at den er vores ansvar, er på den ene side indlysende, og på den anden side er vi langt fra en omsorgsfuld behandling af kroppen. Fedmeepidemien har for alvor sat sig fast $\mathrm{i}$ den vestlige verden, og vi sidder desværre mere og mere foran vores maskiner i en

\section{Litteratur}

Gotved, Helle: Lyd og bevagelse - stemme og krop. Særtryk af Tidsskrift for Legemsøvelser nr. 2/1979. stilling, der vist aldrig har været meningen. Vi er på den ene side meget opmærksomme på kroppen og dens centrale placering $\mathrm{i}$ vores liv, vores velbefinden og vores kommunikation med omverdenen og på den anden side bevidstløst hedonistiske i vores søgen efter selvnydelse. Og så er kroppen igen kommet op til overfladen gennem statslige sundhedstiltag og -lovgivning, der udefra dikterer, hvordan vi skal leve. Der er stadig mange områder at kæmpe for: sundhed er ét af dem. Selv brugte Helle Gotved sjældent dette ord, der i dag skal ind snart sagt alle steder. Sig ordet sundhed, og man kan se den lange række af tiltag, der ser kroppen som noget, der skal reguleres. Midt imellem statsovervåget sundhed og navlebeskuende holisme er der et andet gammelt, nordisk ord - nemlig helse - som Helle Gotved ofte brugte. Dér var måske en pointe... Nu bruger hun ikke flere ord. En epoke, en stemme og et åndedræt døde ud i 2006. Enhver tid har sine bevægelser.

Vi er nu i 2007. Selvom det er februar, er det mildt: 8,2 gr. viser termometret. Jeg tror, jeg vil rejse mig fra skrivebordet og løbe en tur. Solen skinner for $\varnothing v$ vigt.

Man kan læse Helle Gotveds erindringer i »Barn i Gymnastikhuset (1994)《 og »Mit livs gymnastikhistorie (1995)«. For en opsummering af mere faktuelle data henvises til Dansk Kvindeleksikon.
Gotved, Helle: Mit livs gymnastikhistorie. København: Munksgaard/Rosinante 1995 